Discussion Paper No. 08-071

\title{
Barriers to Entry and Profitability
}

Diana Heger and Kornelius Kraft

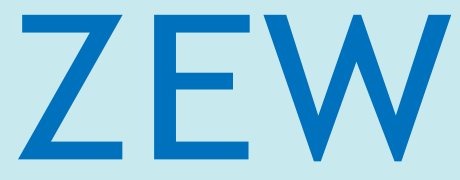

Zentrum für Europäische Wirtschaftsforschung $\mathrm{GmbH}$

Centre for European

Economic Research 
Discussion Paper No. 08-071

\title{
Barriers to Entry and Profitability
}

\author{
Diana Heger and Kornelius Kraft
}

Download this ZEW Discussion Paper from our ftp server:

ftp://ftp.zew.de/pub/zew-docs/dp/dp08071.pdf

Die Discussion Papers dienen einer möglichst schnellen Verbreitung von neueren Forschungsarbeiten des ZEW. Die Beiträge liegen in alleiniger Verantwortung der Autoren und stellen nicht notwendigerweise die Meinung des ZEW dar.

Discussion Papers are intended to make results of ZEW research promptly available to other economists in order to encourage discussion and suggestions for revisions. The authors are solely responsible for the contents which do not necessarily represent the opinion of the ZEW. 


\section{Non-technical summary}

This paper focuses on barriers to entry, firm profitability and the number of firms in a market. Usually, it is expected that high profits attract entry, which is particularly important if the highly profitable firm has a dominant position and holds a large market share. In light of the mechanisms by which markets adjust, the absence of barriers to entry is fundamental for economic welfare. It is necessary that a situation of considerable market power with high profits attracts entry by challengers and that by this intensification of the competitive pressure the profits adjust to a “normal” level.

Baumol et al. (1982) find that market performance depends in an essential way on the importance of potential entry. The problem this raises for econometric work is that potential entry is an unobservable variable. Usually, the effects of entry are identified by the realized entry of challengers. Using survey-based data, we are able to investigate the effect of the threat of entry. Information from top managers, on their perception of how strong their own competitive position is threatened by a likely entry of competitors into their main markets, is applied to estimate what effect this threat of entry has on profitability. We confirm that threat of entry has a disciplinary effect on the price-setting behaviour of firms; we find a significant negative effect of threat of entry on firm profitability.

In a second step, we derive a theoretical model linking the optimal number of firms in a market to fixed costs. Fixed costs should, at least partly, reflect sunk costs which are assumed to build a barrier to entry. The model predicts that the number of firms in a market depends negatively on fixed and marginal costs. We test this model empirically and confirm the conjectured effects. Furthermore, we test whether firms cut prices to such an extent that entry is not profitable. Since threat of entry turns out to have no significant effect on the number of competitors, we can confirm that the cut of prices is sufficient to prevent entry. 


\section{Nichttechnische Zusammenfassung}

Diese Studie betrachtet Markteintrittsbarrieren, Unternehmensprofitabilität und die Anzahl von Unternehmen in einem Markt. Üblicherweise wird angenommen, dass hohe Gewinne Markteintritt hervorrufen, was insbesondere wichtig ist, wenn hochprofitable Unternehmen eine dominante Position und einen großen Marktanteil innehaben. In Bezug auf die Marktmechanismen ist das Fehlen von Markteintrittsbarrieren wichtig für die Wohlfahrt. Es ist unabdingbar, dass in einer Situation beträchtlicher Marktmacht einhergehend mit hohen Gewinnen Markteintritt möglich ist und dass sich durch die Intensivierung des Wettbewerbsdrucks die Gewinne wieder auf ein „normales“ Niveau einpendeln.

Baumol et al. (1982) zeigen, dass die Marktperformance wesentlich von der Bedeutung von potenziellem Markteintritt abhängt. In ökonometrischen Studien wirft dies das Problem auf, dass potenzieller Markteintritt nicht beobachtbar ist. Üblicherweise wird dieser Effekt über sich tatsächlich manifestierten Markteintritt approximiert. Wir sind hingegen in der Lage, durch Nutzung von Unternehmensbefragungen den Effekt von Markteintrittsdrohungen zu analysieren. Informationen von Unternehmensmanagern bzgl. ihrer Wahrnehmung, wie stark die eigene Wettbewerbsposition durch einen wahrscheinlichen Eintritt von Wettbewerbern in ihrem Hauptabsatzmarkt bedroht ist, werden verwendet, um den Effekt zu schätzen, inwieweit die Profitabilität durch Markteintrittsdrohung beeinflusst wird. Wir können den disziplinierende Effekt von Markteintrittsdrohung auf das Preissetzungsverhalten der Unternehmen bestätigen, da wir einen signifikant negativen Effekt der Markteintrittsdrohung auf die Profitabilität finden.

In einem zweiten Schritt leiten wir ein theoretisches Modell her, das die optimale Anzahl von Unternehmen in einem Markt mit Fixkosten verbindet. Fixkosten sollten zumindest teilweise Sunk Costs abbilden, die als Markteintrittsbarriere angesehen werden. Das Modell sagt vorher, dass die Anzahl der Unternehmen in einem Markt negativ von fixen und marginalen Kosten abhängt. Wir testen dieses Modell empirisch und können die theoretisch abgeleiteten Effekte bestätigen. Darüber hinaus, testen wir, ob Unternehmen ihre Preise so stark reduzieren, dass Markteintritt nicht profitabel ist. Da die Markteintrittsdrohung keinen signifikanten Effekt auf die Anzahl der Unternehmen hat, können wir bestätigen, dass die Preissenkungen ausreichend sind, um Markteintritt zu verhindern. 


\title{
Barriers to Entry and Profitability
}

\author{
Diana Heger* and Kornelius Kraft**
}

September 2008

\begin{abstract}
Barriers to entry are regarded as major impediments to the working of markets. Entry must not necessarily actually take place - the perceived threat of entry may encourage incumbent firms to behave as if they are in a competitive market, even if they are not. We present empirical evidence on effects of perceived threat of entry on profitability. Using information from managers about how they assess the existence of entry barriers a strong impact of these assessments on profitability is confirmed. The number and the relative size of competitors also exert considerable effects. We find no statistically significant relation between the perceived threat of entry and the actual number of firms if the size of the relevant market is taken into account.
\end{abstract}

Keywords: Barriers to Entry, Profitability, Discrete Regression Models

JEL-Classification: L13, L25, C25

* Centre for European Economic Research (ZEW) Industrial Economics and International Management L7, 1 68161 Mannheim

Germany

Phone: +49 621 1235-382

Fax: +49 621 1235-170

E-Mail: heger@zew.de
** University of Dortmund

Faculty of Economics

Vogelpothsweg 87

44227 Dortmund

Germany

Phone: +49 231 755-3152

Fax: +49 231 755-3155

E-Mail: k.kraft@wiso.uni-dortmund.de

*, ** Thanks to Georg Licht and the participants of the Brown Bag Seminar for highly valuable comments. 


\section{Introduction}

The observation of short-run high profits is not incompatible with the existence of a long-run competitive equilibrium. Prospective high profits are needed to provide incentives for innovation or any other activity to improve the efficiency of a firm. However, it is expected that in the long-run excessive profits are competed away by reactions of the present competitors, and furthermore, that high profits attract entry, which is particularly important if the highly profitable firm has a dominant position and holds a large market share.

In light of the mechanisms by which markets adjust, the absence of barriers to entry is fundamental for economic welfare. It is necessary that a situation of considerable market power with high profits attracts entry by challengers and that by this intensification of the competitive pressure the profits adjust to a "normal” level.

Economic theory has discussed extensively the conditions for barriers to entry and the effects thereof. Although there is no consensus about the exact definition of what a barrier to entry actually is, it is undeniable that barriers to entry play an important role in a wide variety of competition issues. Entry barriers can retard or even entirely prevent the working of a market and welfare may be seriously affected by them.

There are quite a few empirical studies on the determinants of barriers to entry and also some on the effects of entry on profitability or other variables of interest, e.g. innovation. Martin (2002, 221) notes: “Another such strand is the argument, going back to Bain (1956) and recently re-emphasized by Baumol et al. (1982), that market performance depends in an essential way on the importance of potential entry. The problem this raises for econometric work is that potential entry is an unobservable variable.” Usually, the effects of entry are identified by the realized entry of challengers. However, Martin $(2002,221)$ argues this is not a convincing way to model potential entry, as most actual entry is short and unsuccessful.

Our contribution is a different one: We investigate the effect of the threat of entry. Information from top managers, on their perception of how strong their own competitive position is threatened by a likely entry of competitors into their main markets, is applied to estimate what effect this threat of entry has on profitability.

Aside of the value of using information on the perceived threat of entry we are able to identify the relevant markets as assessed by the managers themselves. 


\section{General Theoretical Considerations}

Entry and exit conditions are important factors that determine existing firms' possibilities to exert market power. A dominant firm with a very high market share might not be able to make use of its position, if any significant deviation of the price from marginal costs will lead to entry by new competitors. Entry by new firms can also affect innovativeness and put pressure on the existing firms not only to refrain from misusing their market power, but also to operate as efficiently as possible. Therefore, cost conditions might also improve. Hence market shares and concentration are just one part of the story; in addition, the conditions for potential competition are important contributors to the functioning of markets.

A firm, deciding whether to penetrate a market or not, compares the benefits and costs of entry. The benefits are the expected profits and growth of demand connected with entry. The costs are, among other things, determined by barriers to entry, which may be caused by exogenous factors like economies of scale ${ }^{1}$ or by strategic factors like excess capacity, limit pricing or advertising.

In the literature, the first important contribution to the discussion of entry barriers is Bain (1956). Following this a lively debate took place which, however, did not succeed in finding a generally accepted definition. Bain defined a barrier to entry by its effects on profitability, in particular in terms of the ability to earn above-normal profits without inducing entry. Stigler (1968) later defines an entry barrier as a cost advantage of incumbents over entrants and von Weizsäcker (1980) argues that a cost differential is only an entry barrier if it reduces welfare ${ }^{2}$. The discussed reasons for barriers to entry are manifold. Economies of scale may or may not be regarded as entry barriers. Clearly, with large scale economies there is only place for a few producers in an industry, and thus entry might be difficult. However, in the view of Baumol, Panzar and Willig (1982) it is the nature of the cost structure which determines entry barriers. In the absence of sunk costs, entry is not impeded and every firm presently active in the industry is disciplined by potential entry. Therefore, prices will be close to average costs. The problem is that in most industries a part of the costs will always be sunk.

\footnotetext{
${ }^{1}$ Whether this is really a barrier to entry is debated.

${ }^{2}$ See McAfee, Mialon and Williams (2004) on this issue.
} 
Excess capacity plays an important role in the theoretical discussion. Spence (1977), Dixit (1979, 1980), Bulow, Geanakoplos and Klemperer (1985) are among the first to point out the asymmetry of an incumbent and a potential entrant. Typically, in such models the incumbent selects a level of capacity in the first period and the potential entrant and the incumbent simultaneously determine quantities in the second period. These models assume that the incumbent produces at or below the capacity limit in the second period and that the incumbent's marginal costs are lower than the potential entrant's marginal costs because the incumbent is able to avoid the costs associated with expanding capacity in the second period. Hence, the incumbent enjoys a first mover advantage.

Another cause of entry barriers is product differentiation. Consumers view products as imperfect substitutes for a number of reasons, such as different varieties (horizontal product differentiation) or product quality (vertical product differentiation). If introducing a new brand is connected with significant fixed costs, horizontal product differentiation may well lead to persistent entry barriers. Shaked and Sutton $(1982,1983)$ analyse a game where firms choose whether to enter at the first stage of the game, choose quality at the second stage and prices at the third stage. Surprisingly, they show in their model that only a few and at the limit only one firm will operate in the industry despite of free entry.

Obviously, firms have an interest in product differentiation and they will attempt to increase the perceived difference or quality advantage of their products by the use of advertising. Advertising intends to increase consumers' loyalty to specific brands, and therefore, to deter entry. Clearly, advertising expenditures are sunk costs and can as such increase the impediments to enter a market. This is the way advertising is introduced into the Sutton model. It can, however, also be argued that advertising informs consumers about the existence and the characteristics of new products, and thus, eases entry.

Another possible way of incumbents to raise entry barriers is by innovation. Bain (1956) already identifies absolute cost advantages as a major reason for entry barriers, and obviously, process innovation that aims at cost reductions. Secondly, newly developed products will lead to (at least temporary) advantages compared to competitors and therefore R\&D activities can lead to reduced entry. At this point, it can also be argued in the opposite direction, as many entering firms are new foundations of innovators, who want to benefit from the market potential of their inventions. Hence innovativeness might spur entry and not impede it. 


\section{A Model with Fixed Costs}

We consider a representative firm $i$ which competes with $n-1$ other producers in a Cournot oligopoly $^{3}$. In addition to constant marginal costs $c$ every firm has to cover fixed costs $F$, which are completely sunk ${ }^{4}$. The inverse demand function is defined in the following (standard) way:

(1) $\mathrm{p}_{\mathrm{i}}=\mathrm{a}-\mathrm{bq}_{\mathrm{i}}-\mathrm{b}(\mathrm{n}-1) \mathrm{q}_{\mathrm{j}}$

where the price demanded by firm $i\left(p_{i}\right)$ depends on the reservation price, the output level of firm $i\left(q_{i}\right)$ and the individual outputs of all other competitor firms $\mathrm{j}\left(q_{j}\right)$. All outputs are characterized by the same price elasticity $b$.

These assumptions lead to a simple profit function:

$$
\pi_{\mathrm{i}}=\left(\mathrm{a}-\mathrm{bq}_{\mathrm{i}}-\mathrm{b}(\mathrm{n}-1) \mathrm{q}_{\mathrm{j}}\right) \mathrm{q}_{\mathrm{i}}-\mathrm{cq}_{\mathrm{i}}-\mathrm{F} \text {. }
$$

Optimizing this function with respect to output $\mathrm{q}_{\mathrm{i}}$, and solving, assuming homogenous firms with identical output levels, leads to:

$$
\mathrm{q}=\frac{\mathrm{p}-\mathrm{c}}{\mathrm{b}}=\frac{\mathrm{a}-\mathrm{bnq}-\mathrm{c}}{\mathrm{b}}=\frac{\mathrm{a}-\mathrm{c}}{\mathrm{b}(\mathrm{n}+1)}
$$

Equation (3) shows that the optimal output level $q$ of every competitor depends negatively on the marginal costs $c$ and on the number of firms $n$ active in the market.

Since a general assumption is that entry occurs until all profit is dissipated, we determine the optimal number of firms in a market by solving the zero profit condition. As firms' sales (s) are identical, they can be defined as the average industry sales $(S / n)$ determined by the optimal output level $q$ derived in equation (3).

$$
\frac{\mathrm{S}}{\mathrm{n}}-\mathrm{cq}-\mathrm{F}=\frac{\mathrm{S}}{\mathrm{n}}-\mathrm{c} \frac{\mathrm{a}-\mathrm{c}}{\mathrm{b}(\mathrm{n}+1)}-\mathrm{F}=0 .
$$

\footnotetext{
${ }^{3}$ Breshnahan and Reiss $(1990,1991)$ and Berry (1992) discuss the relation between market size and the number of firms. Clearly, Sutton $(1991,1998)$ is also highly relevant if this question is considered. Cf. also the surveys by Berry and Reiss (2006) and Sutton (2006).

${ }^{4}$ The assumption that all fixed costs are sunk is used for simplicity. Any sunk costs larger than zero would produce results similar to the ones presented below. If fixed costs are not sunk an entrant would not take them into account, as they can be recovered after leaving the industry. However in practice a part of capital will always be sunk.
} 
Solving for $n$, leads to the following expression:

$$
\mathrm{n}=\frac{\mathrm{Sb}-\mathrm{ac}+\mathrm{c}^{2}-\mathrm{bF}+\left(\left(\mathrm{Sb}-\mathrm{ac}+\mathrm{c}^{2}-\mathrm{bF}\right)^{2}+4 \mathrm{~b}^{2} \mathrm{FS}\right)^{\frac{1}{2}}}{2 \mathrm{bF}}
$$

The industry sales volume $S$ is simply defined as $S=p n q$. Replacing $q$ by the optimal output determined by (3) and also including (3) into the inverse demand function (1) leads to:

(6) $\quad \mathrm{S}=\mathrm{pnq}=\frac{(\mathrm{a}+\mathrm{nc}) \mathrm{n}(\mathrm{a}-\mathrm{c})}{\mathrm{b}(\mathrm{n}+1)^{2}}$.

This relation is inserted into the equation (5), and solving for $n$, leads to an explicit expression for the number of firms in a market $(n)$ :

$$
\mathrm{n}=-1+\frac{\mathrm{a}-\mathrm{c}}{\sqrt{\mathrm{bF}}}
$$

This relation implies that the maximal number of firms falls with a larger fixed costs $F$ as well as with higher marginal costs $c$, and rises with $a$. More interesting, however, is the average firm size, as the costs have opposing effects: On the one hand in the absence of entry barriers higher costs lead to a lower output level. On the other hand fixed as well as marginal marginal costs restrict the number of firms and therefore increase the market shares of the existing firms. Hence, both the nominator and the denominator of $n / S$ are affected by the cost conditions and it remains unclear which effect dominates. The number of firms in an industry is determined by the following condition:

$$
\frac{\mathrm{n}}{\mathrm{S}}=\frac{\mathrm{b}}{\mathrm{bF}+\mathrm{c}(\mathrm{bF})^{\frac{1}{2}}} .
$$

The number of firms in an industry is negatively affected by fixed costs $F$ as well as by marginal costs $c$. Thus, this implies in turn that average firm size is positively affected by both $F$ and $c$. Given that output is reduced if marginal costs $c$ rise, this result is not self-evident. Surprisingly, the constant term of the demand curve, $a$, has no effect on the maximal number of firms.

The model is based on the assumption of entry until profits are dissipated. In such a scenario, by construction a connection between fixed costs and profitability cannot exist as profits are always zero. However, this is clearly the result of ignoring the integer constraint on the number of competitors $n$. If the integer condition is taken into account, raising fixed costs can lead 
to higher profits as the size of the market may not be large enough to allow entry of an additional firm, but the incumbents earn positive profits.

$$
\frac{\mathrm{S}}{\mathrm{n}_{0}}-\mathrm{cq}_{\mathrm{n}_{0}}-\mathrm{F}>0 \geq \frac{\mathrm{S}}{\mathrm{n}_{0}+1}-\mathrm{cq}_{\mathrm{n}_{0}+1}-\mathrm{F}
$$

As an example, assume $\mathrm{a}-\mathrm{c}=2$ and $\mathrm{b}=\mathrm{F}=1$, which results in $\mathrm{n}=1$ and $\pi=0$. If fixed costs are now slightly reduced to 0.9 , the new n connected with zero profits is 1.108 . As this is not an integer, with $n=1$ the incumbent realises profits of 0.1 . If entry occurs and $n=2$, profits become negative. Hence, in this situation the incumbent takes profits and entry will not occur.

This opportunity for positive profits will be larger, the higher the fixed costs are. Comparing the profit levels without $\left(\pi_{\mathrm{n}_{0}}\right)$ and with entry $\left(\pi_{\mathrm{n}_{0}+1}\right)$ leads to:

$$
\pi_{\mathrm{n}_{0}}-\pi_{\mathrm{n}_{0}+1}=\frac{\left(\mathrm{a}+\mathrm{n}_{0} \mathrm{c}\right)(\mathrm{a}-\mathrm{c})}{\left(\mathrm{n}_{0}+1\right)^{2} \mathrm{~b}}-\frac{\mathrm{c}(\mathrm{a}-\mathrm{c})}{\mathrm{b}\left(\mathrm{n}_{0}+1\right)}-\frac{\left(\mathrm{a}+\left(\mathrm{n}_{0}+1\right) \mathrm{c}\right)(\mathrm{a}-\mathrm{c})}{\left(\mathrm{n}_{0}+2\right)^{2} \mathrm{~b}}+\frac{\mathrm{c}(\mathrm{a}-\mathrm{c})}{\mathrm{b}\left(\mathrm{n}_{0}+2\right)}
$$

The derivative of this profit difference with respect to $n_{0}$ is, as expected, negative. Hence the profit reduction induced by entry is decreasing in $n$. Clearly, the maximal number of firms $n$, which is compatible with non-negative profits, is decreasing in fixed costs F, and therefore, the potential for realising profits without attracting entry is increasing in F. The maximal number of firms is also decreasing in marginal costs.

\section{Empirical Test}

We estimate two models. The first model analyzes the effect of entry threat on firm's profitability. The second model is based on the theoretical model derived in Section 3 and estimates the number of firms in dependence of fixed and marginal costs. In order to test our hypotheses on the threat of entry, we use firm level information from the Mannheim Innovation Panel (MIP). Data collection is carried out by the Centre for European Economic Research (ZEW) on behalf of the Federal Ministry of Education and Research. The MIP provides annual information on innovative behaviour in the German manufacturing sector between 1992 and 2005. The MIP is also the German contribution to the CIS, the European Community Innovation Survey. Table 2 displays the descriptive statistics. 


\subsection{Threat of Entry and Profitability}

A number of empirical studies on barriers to entry already exist. They usually investigate the determinants of and/or impediments to market entry (and exit). Some also investigate the profitability effects. With respect to the latter relation, Amel and Liang (1997) find that new entrants in banking markets are attracted by high profits, market size and growth and that entry reduces market power in pricing. The studies on the determinants of entry barriers address the question of natural or strategic barriers like scale economies, excess capacity, limit pricing, product differentiation by means of advertising or innovative activity. Furthermore, the benefits of entry into a particular market are regarded by taking account of expected profitability and market growth ${ }^{5}$. The empirical evidence is quite supportive and unambiguous concerning profitability and market growth, but, in the summarizing view of Siegfried and Evans (1994), is much less convincing with respect to the other determinants like scale economies, excess capacity, limit pricing and product differentiation.

The effect of the threat of entry on pricing behaviour, and therefore, also on profitability of firms is much less frequently investigated, although it has a strong rooting in theory. Harrod (1952) already suggests that if entry is easy, the incumbents will set prices close to average costs. This perception of the working of markets is also at the centre of the theory of Baumol, Panzar and Willig (1982). We intend to estimate the impact of perceived threat of entry on the profitability of companies. This perceived threat of entry is expected to determine the pricing behaviour of firms. Firms which are producing in easy-to-enter industries should be disciplined by this potential competition, even if entry does not occur in practice. Perhaps some firms will decide to optimize by maximizing short-run profits, and accept that in the long run entry takes place and profits will erode. This is basically Gaskins’ (1971) argument.

Our empirical study investigates the determinants of profitability. The dependent variable is the profit margin. This variable is sometimes called excess return on sales and expresses the following:

$$
\frac{\pi_{i}}{s_{i}}=\frac{s_{i}-\text { labor cost }}{i}-{\text { capital } \operatorname{cost}_{i}-{\text { material } \operatorname{cost}_{\mathrm{i}}}}_{s_{i}}
$$

\footnotetext{
${ }^{5}$ A recent example is Berger, Bonime, Goldberg and White (2004).

${ }^{6}$ One could argue that the subjective assessment could also be based on the objectively observed frequent entry of challengers into a market. However this assertion is rejected by our empirical results. See below.
} 
with $\pi_{i}$ denoting profits and $s_{i}$ being firm (not industry) sales. If firms are in the long-run equilibrium and are operating within the range of their production functions with constant returns to scale, the excess profit return on sales will, on average across all products produced by the firm, equal the Lerner index. With constant returns to scale marginal costs $(c)$ are equal to average costs $(A C)$. One can therefore write:

$$
\frac{\pi}{s}=\frac{p q-A C q}{p q}=\frac{p-c}{p}
$$

with $p$ being the price and $q$ the quantity produced. Hence, our measure is the price-cost margin, where the capital costs have been subtracted and need not be taken into account by capital divided by sales as an explanatory variable as in other empirical models considering the price cost margin $^{7}$.

Table 1: Surveyed categories of the return on sales

\begin{tabular}{cccccc}
\hline Return on sales & Class & Return on sales & Class & Return on sales & Class \\
\hline$<0 \%$ & 0 & $(4-7 \%]$ & 3 & $>15 \%$ & 6 \\
$(0-2 \%]$ & 1 & $(7-10 \%]$ & 4 & don't know & 7 \\
$(2-4 \%]$ & 2 & $(10-15 \%]$ & 5 & & \\
\hline
\end{tabular}

The categorical variable return on sales was included in the 2003 and 2005 surveys. The information is available for the years 2001 to 2004 because in both surveys firms were asked to state the return on sales for the two years preceding the survey year. Information on exports, the number of employees, sales and capital intensity has been taken from the respective waves. As can be seen in the descriptive statistics depicted in Table 2, the average firm generates between 2 and $7 \%$ of return on sales as the mean represents the average category number.

In the given context, the most important variable is the threat of entry. We use the threat and not the actually occurring entry rates as the explanatory variable because our main hypothesis is that the firms take action themselves to deter entry by reducing prices if entry is a definite possibility. Hence, the subjective assessment of the entry conditions is decisive, in our view, to explain profitability.

\footnotetext{
${ }^{7}$ The usual way to estimate price-cost margins was introduced by Collins and Preston (1969). There are numerous studies that follow the same methodology.
} 
This seems to be one of the few cases where the use of subjective data is totally appropriate. The subjective impression of the managers concerning potential entry determines their pricing decisions and the resulting profitability. As stated above, the subjective assessment may be the result of observing that entry actually takes place, in which case there would be no difference between the objective situation and the subjective evaluation. The variable concerning entry is based on the following question: "Please indicate, in how far the following criteria describe the competitive situation in your main market: High threat to your firm's market position by entry of new competitors". The evaluations are rated on a four point Likert scale ranging from “fully applies” to “does not apply at all”. We use a dummy variable, which assumes unit value if a firm ticks the box "fully applies".

Clearly, any study analysing profitability has to carefully take into account the competitive situation in general. In our case, we do this in two different ways. We use information concerning the relevant market supplied by the firms themselves. They were asked to evaluate how many main competitors they have. The options proposed for their assessments were "none”, "1 to 5", “6 to 15 " and "more than 15 ". We compute a dummy variable called intermediate competition, which has unit value if the firm chooses the option "6 to 15" and secondly a dummy variable called intensive competition if the firm chooses the option "more than 15”. We suppose that the evaluation of the situation by the firm itself offers a more accurate representation of competitive pressure than conventional concentration indices.

Next we take account of the size structure of the competitors. We use a dummy variable called competitors size, which has unit value, if a firm expresses that the competitors are predominantly larger than the firm itself. We have also information on the importance of price competition. Firms were asked to rank the importance of several characteristics of their competitive environment (product quality, technical advancement, service, product variety, advertising and price). If the option "price” was given the highest priority, we create a dummy variable with unit value. This variable is called strong price competition.

The questions on threat of entry and competition were only included in the year 2005 and represent the competitive situation in 2004. We conjecture that neither the threat of entry, nor competition, nor buyer power change much in the short-run. Therefore, we hold these variables constant over time for the observation period of 2001 to 2004. In Table 2, we find that about $14 \%$ of the firms think that the market in which they operate is characterized by potential market entry. Over $13 \%$ of the firms are exposed to intensive competition, in that they 
face more than 15 competitors, and almost a third of the firms experience intermediate competition and compete with 6 to 15 firms. Furthermore, more than $36 \%$ of the firms face competitors that are larger than themselves (competitors size).

Table 2: Descriptive Statistics

\begin{tabular}{lcccc}
\hline Variable & Mean & Std. Dev. & Min & Max \\
\hline RETURN ON SALES & 2.341 & 1.716 & 0 & 6 \\
1/SALES** & 0.295 & 0.479 & 0.000 & 5 \\
\hline THREAT OF ENTRY & 0.136 & 0.343 & 0 & 1 \\
INTENSIVE COMPETITION & 0.134 & 0.341 & 0 & 1 \\
INTERMEDIATE & 0.245 & 0.428 & 0 & 1 \\
COMPETITION & 0.361 & 0.480 & 0 & 1 \\
COMPETITORS SIZE & 0.487 & 0.500 & 0 & 1 \\
STRONG PRICE COMPETITION & 0.007 & 0.084 & -0.624 & 0.885 \\
DEMAND GROWTH* & 0.235 & 0.251 & 0 & 0.919 \\
EXPORT & 0.251 & 0.134 & 0.060 & 0.712 \\
IMPORT & 0.097 & 0.152 & 0.000 & 1.956 \\
KAPINT & 72.100 & 30.830 & 9.779 & 195.583 \\
SALARIES AND WAGES & 361.738 & 1173.939 & 1.001 & 20777.96 \\
INDUSTRY SALES & 4.379 & 1.538 & 1.609 & 10.971 \\
Log(EMPLOYEES) & 0.347 & 0.476 & 0 & 1 \\
EAST & & & & \\
\hline
\end{tabular}

* Lagged values.

** Sales is measured in thousand $€$.

Another important impact factor for profitability linked to consumers is the market potential, which is often reflected by the lagged market demand growth proxied by the growth of sales at the three-digit industry level which is calculated as follows:

$$
\text { demand growth } h_{s t}=\frac{S_{s t}-S_{s, t-1}}{S_{s, t-1}}
$$

where the demand growth in sector $s$ at time $t$ depends on the change in sales $(S)$. As concerns the industry-level variable market demand, we combine information gathered in the biennially published report of the German Monopoly Commission which provides industry sales at the three-digit NACE level. Industry sales are used to compute each firm's market share and sales 
growth rates which proxy the demand growth and hence the market potential. Profitability as well as the need to react to potential entry also depends on the market potential, which is often reflected by the lagged market demand growth. The average firm faces a market demand growth of $0.7 \%$ per year.

More conventional control variables are the market share measured as the fraction of firm sales to 3-digit industry sales, the firm's share of sales exported and industry imports divided by the sum of industry imports and industry production at 2-digit level (import) and the capital intensity kapint (capital fixed and working/number of employees). Clearly, all four variables are also used to represent the competitive environment of a firm and the industry. east is a dummy variable, which indicates that the firm is situated in the Eastern part of Germany (the former GDR). Finally, we add industry and time dummies, because other specific circumstances in an industry and/or cyclical factors, which perhaps are not reflected by our other variables, may affect the returns.

In order to test the effects of potential entry on profitability we estimate an ordered probit for return on sales which is measured categorically as described in Table 1. As usual, in the context of discrete choice, the model is based on a latent variable $y^{*}$ (here: profitability) being explained in a linear manner by $x^{\prime} \beta$. Since the latent variable is unobserved we rely on its surveyed categorical values. The econometric model can be written as,

$$
\begin{aligned}
& y_{i}^{*}=x_{i}^{\prime} \beta+\varepsilon_{i} \text { with } i=1, \ldots, N \\
& y=\left\{\begin{array}{l}
0 \text { if } \mathrm{y}_{\mathrm{i}}^{*} \leq \mu_{0} \\
1 \text { if } \mu_{0}<\mathrm{y}_{\mathrm{i}}^{*} \leq \mu_{1} \\
\vdots \\
6 \text { if } \mathrm{y}_{\mathrm{i}}^{*}>\mu_{5}
\end{array}\right.
\end{aligned}
$$

As opposed to the usual ordered probit case, the cut-off points $\mu_{k}$ are known (see Table 1). Thus, the thresholds need not be estimated. Furthermore, by using the true threshold values we are able to identify the variance and to interpret the estimated coefficients as in a linear regression model, i.e. as marginal effects of the latent model (see Czarnitzki and Kraft (2004a,b) and Verbeek (2000) p. 192-195 for an example).

Since heteroscedasticity will lead to inconsistent estimates we account for groupwise multiplicative heteroscedasticity of the form $\sigma_{i}=\sigma \exp \left(z_{i} \alpha\right)$ where $\mathrm{z}$ is a vector of variables sus- 
pected to cause heteroscedasticity. If heteroscedasticity is an issue in the ordered probit, $\alpha$ are additional coefficients to be estimated. In order to test if heteroscedasticity is an issue in our estimation, we perform LR tests. Heteroscedasticity is modelled by industry and time dummies, by the east dummy and by firm size dummies. The LR tests show that that assumption of homoscedasticity has to be rejected.

Table 3: Results for homo- and heteroscedastic ordered probits with known thresholds

\begin{tabular}{|c|c|c|c|c|}
\hline & Homosc. & Heterosc. & Homosc. & Heterosc. \\
\hline & $\begin{array}{c}\text { Coef. } \\
\text { (Std.Err.) }\end{array}$ & $\begin{array}{c}\text { Coef. } \\
\text { (Std.Err.) }\end{array}$ & $\begin{array}{c}\text { Coef. } \\
\text { (Std.Err.) }\end{array}$ & $\begin{array}{c}\text { Coef. } \\
\text { (Std.Err.) }\end{array}$ \\
\hline Threat of entry & $\begin{array}{c}-0.006^{* *} \\
(0.003)\end{array}$ & $\begin{array}{c}-0.007 * * * \\
(0.003)\end{array}$ & $\begin{array}{c}-0.005^{*} \\
(0.003)\end{array}$ & $\begin{array}{c}-0.005^{* *} \\
(0.003)\end{array}$ \\
\hline intensive comp. & $\begin{array}{c}-0.010^{* * *} \\
(0.003)\end{array}$ & $\begin{array}{c}-0.011^{* * *} \\
(0.003)\end{array}$ & $\begin{array}{c}-0.008^{* * *} \\
(0.003)\end{array}$ & $\begin{array}{c}-0.009 * * * \\
(0.003)\end{array}$ \\
\hline intermediate comp. & $\begin{array}{c}-0.009 * * * \\
(0.002)\end{array}$ & $\begin{array}{c}-0.009 * * * \\
(0.002)\end{array}$ & $\begin{array}{c}-0.007 * * * \\
(0.002)\end{array}$ & $\begin{array}{c}-0.007^{* * *} \\
(0.002)\end{array}$ \\
\hline comp. size & $\begin{array}{c}-0.005^{* * *} \\
(0.002)\end{array}$ & $\begin{array}{c}-0.005^{* *} \\
(0.002)\end{array}$ & $\begin{array}{c}-0.006^{* * *} \\
(0.002)\end{array}$ & $\begin{array}{c}-0.005^{* * *} \\
(0.002)\end{array}$ \\
\hline strong price comp. & & & $\begin{array}{c}-0.012 * * * \\
(0.002)\end{array}$ & $\begin{array}{c}-0.012 * * * \\
(0.002)\end{array}$ \\
\hline demand growth ${ }^{a}$ & $\begin{array}{c}0.045^{* * * *} \\
(0.012)\end{array}$ & $\begin{array}{c}0.045 * * * \\
(0.011)\end{array}$ & $\begin{array}{c}0.042^{* * * *} \\
(0.011)\end{array}$ & $\begin{array}{c}0.041^{* * *} \\
(0.011)\end{array}$ \\
\hline Import & $\begin{array}{c}0.001 \\
(0.010)\end{array}$ & $\begin{array}{c}-0.002 \\
(0.010)\end{array}$ & $\begin{array}{l}-0.003 \\
(0.010)\end{array}$ & $\begin{array}{c}-0.006 \\
(0.010)\end{array}$ \\
\hline Export & $\begin{array}{c}0.016^{* * * *} \\
(0.004)\end{array}$ & $\begin{array}{c}0.016^{* * * *} \\
(0.004)\end{array}$ & $\begin{array}{c}0.014^{* * *} \\
(0.004)\end{array}$ & $\begin{array}{c}0.014^{* * * *} \\
(0.004)\end{array}$ \\
\hline log(employees) & $\begin{array}{c}-0.001 \\
(0.001)\end{array}$ & $\begin{array}{c}-0.001 \\
(0.001)\end{array}$ & $\begin{array}{c}-0.001 \\
(0.001)\end{array}$ & $\begin{array}{c}-0.001 \\
(0.001)\end{array}$ \\
\hline capital intensity & $\begin{array}{c}0.013 * * \\
(0.006)\end{array}$ & $\begin{array}{c}0.015^{* *} \\
(0.006)\end{array}$ & $\begin{array}{c}0.014 * * \\
(0.006)\end{array}$ & $\begin{array}{c}0.016^{* * *} \\
(0.006)\end{array}$ \\
\hline East & $\begin{array}{c}-0.002 \\
(0.002)\end{array}$ & $\begin{array}{c}-0.001 \\
(0.002)\end{array}$ & $\begin{array}{l}-0.001 \\
(0.002)\end{array}$ & $\begin{array}{l}-0.000 \\
(0.002)\end{array}$ \\
\hline Constant & $\begin{array}{c}0.030 * * * \\
(0.007)\end{array}$ & $\begin{array}{c}0.029 * * * \\
(0.007)\end{array}$ & $\begin{array}{c}0.038 * * * \\
(0.007)\end{array}$ & $\begin{array}{c}0.036^{* * * *} \\
(0.007)\end{array}$ \\
\hline industry dummies & included & included & included & included \\
\hline time dummies & included & included & included & included \\
\hline Sigma & $\begin{array}{c}0.051^{* * * *} \\
(0.001)\end{array}$ & $\begin{array}{c}0.052 * * * \\
(0.003)\end{array}$ & $\begin{array}{c}0.051^{* * *} \\
(0.001)\end{array}$ & $\begin{array}{c}0.053^{* * *} \\
(0.003)\end{array}$ \\
\hline log likelihood & -6855.02 & -6817.92 & -6834.88 & -6794.53 \\
\hline$\chi^{2}(\text { all })^{a}$ & $199.10^{* * *}$ & $216.09 * * *$ & $157.66^{* * *}$ & $166.91^{* * *}$ \\
\hline$\chi^{2}$ (industries) $^{b}$ & $41.98 * * *$ & $92.49 * * *$ & $43.36 * * *$ & $89.06 * * *$ \\
\hline$\chi^{2}(\text { time })^{c}$ & 0.58 & 1.99 & 0.63 & 2.72 \\
\hline LR-test(het.) ${ }^{d}$ & & $80.71^{* * *}$ & & $74.21^{* * *}$ \\
\hline joint sig.(het.) $)^{e}$ & & $80.33 * * *$ & & $73.35 * * *$ \\
\hline Number of obs. & 3626 & 3626 & 3626 & 3626 \\
\hline
\end{tabular}


Table 3 displays the results of the ordered probit with known cut-off points. Our hypothesis that the threat of entry reduces profitability is confirmed. The results show a negative significant effect of threat of entry on return on sales, and hence, disciplining effect with respect to setting above normal prices.

Regarding the control variables, return on sales seems to be sensitive to market conditions. Profitability depends negatively on competition, either intensive or intermediate, and is negatively influenced by the size of the competitors. This reflects the mechanism that stronger competitive pressure forces the firms to lower prices, and hence, to accept a reduction in return on sales. Price competition has also a negative impact on profitability. Notice, that the threat of entry has an independent effect aside of the number of competitors. Similarly, the threat of entry has an independent and additional impact if the variable price competition is included. This is not self-evident, as we hypothesize that the threat of entry leads to price reductions, and therefore, a high correlation is probable. Furthermore, firms' profitability is strengthened if other proxy variables standing for barriers to entry exist. We measure barriers to entry by firm's capital intensity and find a positive effect on profitability. Moreover, the market potential is a crucial factor for firm profitability; demand growth has a significant positive effect on return on sales. And finally, exports generate higher return on sales.

\subsection{Number of Competitors in a Market}

One possible strategy to avoid entry could be to reduce prices to such an extent that entry is no longer profitable. If this were true, we would not observe a statistical association between the threat of entry and the number of competitors. The absence of entry barriers does not necessarily imply a larger number of active competitors if incumbents act strategically.

There is an interesting literature on the determinants of the number of firms active in an industry. Sutton (1991, 1998, 2006) develops a theory of a lower bound of concentration. He considers exogenous and endogenous barriers to entry. If entry barriers are largely exogenously given, the minimum value of concentration tends to zero as market size increases. However, if fixed costs are endogenously determined by advertising and/or research and development, Sutton predicts that the minimum equilibrium value of concentration is bounded from below. The equilibrium value of the number of firms is among other things determined by the toughness of competition, with a Bertrand oligopoly as the toughest market structure. 
Breshanahan and Reiss (1991), Berry and Reiss (2006) discuss and estimate entry into small markets. They identify entry thresholds and ratios of entry thresholds revealing the nature of competition and the relevance of fixed costs. A recent empirical study on the relation between market size and the size distribution of firms is Campbell and Hopehayn (2005).

The model developed in Section 3 shows that it is of utmost importance to identify $n / S$ and not just $n$, as the number of active firms will usually but not necessarily rise with market size. In order to assess the size of the relevant market, we restrict our sample to those firms which indicate that their rivals are of similar size. This procedure implies that our dependent variable is $n /\left(n * s_{i}\right)=1 / s_{i}$, i.e. the inverse of individual firm sales ${ }^{8}$.

As derived in the model in Section 3, the number of firms, which can survive in a market, is obviously also determined by cost conditions. Both fixed and marginal costs are expected to reduce the number of firms. These costs are approximated by capital intensity kapint (reflecting the extent of fixed costs) and the average salaries and wages per employee including the firms’ contributions to social security (representing marginal costs).

It cannot be excluded that we may encounter endogeneity problems. Schmalensee (1989) argues that cross sectional studies are prone to simultaneity problems and our approach might not be free of such feed back relations. However, it is impossible to find reliable instrumental variables. On the other hand, it seems to be quite unlikely that endogeneity is responsible for our main results.

As described above, Sutton (1991, 1998, 2006) emphasises the role of toughness of price competition on the number of competitors. If competitive pressure is strong, as in the case of Bertrand behaviour, fewer firms are supported in equilibrium, as a greater increase in market size is required for an additional profitable entry to take place. This hypothesis is tested by our variable strong price competition, defined similarly as in the last section.

Sutton also points to a non-linear relation between the number of firms and industry size, as output per firm is expected to rise with total industry sales. However, a test on this hypothesis is not trivial in our case. We have no exact information on the number of firms active in an

\footnotetext{
${ }^{8}$ This variable is thus directly comparable to the dependent variable establishments' sales, used by Campell and Hopenhayn (2005).
} 
industry, but instead use the responses to our alternative categories. These answers are now used to approximate the number of firms in the following way: If a firm indicates that it has 1 to 5 main competitors, we compute the total number by adding to the average number of 3 competitors the interviewed firm itself, which results in a total of 4 firms active in the respective industry. If a firm states that it has 6-15 main competitors, our estimate of the industry structure amounts to a total of 11 companies. Finally, if a firm chooses to tick the option "more than 15 competitors", we take 20 as a rough "guesstimate" of the total number of active firms. These figures are multiplied by the sales of the responding firm. Clearly, this procedure is somewhat arbitrary, but we see no alternative method to test for a possible nonlinear relation between market size and the number of firms.

As before, we add nine industry dummies to control for specific circumstances characterizing a market. The dummy variable east is included, as the firms in the new Bundesländer (the former GDR) are on average younger and smaller than their Western counterparts.

Our test of the impact of potential entry on the number of competitors in a market is based on OLS regressions with robust standard errors. Estimation results are presented in Table 5. It turns out that the threat of entry is not associated with a significantly higher number of competitors. Hence, the threat alone is sufficient to induce the incumbents to cut prices to such an extent that entry is no longer profitable. As shown in the section on profitability, taking into account the independent effect of the number of competitors, the threat of entry implies significantly reduced profits and this reduction in profitability seems to be sufficient to avoid any occurrence of entry. The insignificance of the coefficient of entry threat is very robust and does also not alter if, for instance, the variables considered in the profitability equation are additionally included. This outcome of our empirical study also offers evidence against the possibility that the firms base their assessment of the existence of entry barriers on the mere observation that entry actually occurs.

Our cost variables have the expected effects and are both significant. We find evidence for a non-linear relation between industry size and the number of companies. Furthermore, we find a strong impact of price competition on the total number of competitors which supports our conjecture that Bertrand competition leads to a smaller number of firms in a market. 
Table 5: OLS Regressions for the Number of Firms Active in a Market

\begin{tabular}{|c|c|c|c|}
\hline & $\begin{array}{c}\text { Coeff. } \\
\text { (Std.Err.) }\end{array}$ & $\begin{array}{c}\text { Coeff. } \\
\text { (Std.Err.) }\end{array}$ & $\begin{array}{c}\text { Coeff. } \\
\text { (Std.Err.) }\end{array}$ \\
\hline THREAT OF ENTRY & $\begin{array}{c}0.041 \\
(0.051)\end{array}$ & $\begin{array}{c}0.054 \\
(0.051)\end{array}$ & $\begin{array}{c}0.058 \\
(0.051)\end{array}$ \\
\hline $\begin{array}{l}\text { STRONG } \\
\text { COMPETITION }\end{array}$ & & $\begin{array}{c}-0.086 * * * \\
(0.030)\end{array}$ & $\begin{array}{c}-0.086 * * * \\
(0.030)\end{array}$ \\
\hline INDUSTRY SALES & & & $\begin{array}{l}-1,9 * \mathrm{e}^{-5} * * * \\
\left(4.9 * \mathrm{e}^{-6}\right)\end{array}$ \\
\hline KAPINT & $\begin{array}{c}-0.098 * * * \\
(0.021)\end{array}$ & $\begin{array}{c}-0.094 * * * \\
(0.021)\end{array}$ & $\begin{array}{c}-0.084 * * * \\
(0.022)\end{array}$ \\
\hline SALARIES AND WAGES & $\begin{array}{c}-0.380 * * * \\
(0.052)\end{array}$ & $\begin{array}{c}-0.380 * * * \\
(0.052)\end{array}$ & $\begin{array}{c}-0.371 * * * \\
(0.053)\end{array}$ \\
\hline EAST & $\begin{array}{c}0.043 \\
(0.035)\end{array}$ & $\begin{array}{c}0.053 * * \\
(0.034)\end{array}$ & $\begin{array}{c}0.051 \\
(0.034)\end{array}$ \\
\hline CONSTANT & $\begin{array}{c}1.699 * * * \\
(0.200)\end{array}$ & $\begin{array}{c}1.739 * * * \\
(0.202)\end{array}$ & $\begin{array}{c}1.710 * * * \\
(0.204)\end{array}$ \\
\hline INDUSTRY DUMMIES & included & included & included \\
\hline TIME DUMMIES & included & included & included \\
\hline$R^{2}$ & 0.166 & 0.167 & 0.171 \\
\hline$F(a l l)^{a}$ & $20.85^{* * *}$ & $19.84^{* * *}$ & $19.21^{* * *}$ \\
\hline$F(\text { industry })^{b}$ & $18.61 * * *$ & $18.74 * * *$ & $17.69 * * *$ \\
\hline$F(\text { time })^{c}$ & 0.12 & 0.11 & 0.12 \\
\hline Number of Observations & 2366 & 2366 & 2366 \\
\hline
\end{tabular}

\section{Conclusions}

This paper reports the results of a study which employs rarely available variables. We investigate the effects of the perceived threat of entry on profitability and the number of competitors. The entry threat leads to lower profits, and the reduction in profits is sufficient to make entry unattractive, as our variable entry threat is actually not associated with a higher number of firms.

While subjective data is usually criticised for its limited reliability, we think it is quite useful in the present context. The subjective assessment of managers concerning the characteristics 
of the markets in which their firms operate will determine firm behaviour. Obviously, the view of the managers may eventually later turn out to have been wrong, but nevertheless the individual evaluation serves as the basis of their decisions.

The observed market structure and market performance are among other things determined by strategic decisions of firms. This paper aims to identify one reason for strategic behaviour of firms and the consequences thereof. Clearly, there is much scope left for additional research on the decisions of firm managers in situations of imperfect competition, but it is very difficult to observe not only the outcome but also the reasons for market conduct.

It is obvious that much of the analysis could be improved by the use of panel data. Beforeafter comparisons would help to solve or attenuate the diverse endogeneity and causality issues, which can hardly be totally avoided in the case of cross-sectional data. However we make use of very specific variables and we are glad to have them at all, and a panel is probably too much to ask for at the present time.

\section{References}

Amel, D.F. and Liang, J.N. (1997), Determinants of Entry and Profits in Local Banking Markets, Review of Industrial Organization 12, 59-78.

Bain, J. S. (1956), Barriers to New Competition, Harvard University Press, Cambridge, MA.

Baumol, W. J., Panzar, J. C. and Willig, R.D. (1982), Contestable Markets and the Theory of Industry Structure, Harcourt Brace Jovanovich, New York.

Berger, A.N., Bonime, S. D., GoldbergL.G. and White, L.J. (2004), The Dynamics of Market Entry: The Effects of Mergers and Acquisitions on Entry in the Banking Industry, Journal of Business 77, 797-834.

Berry, S. and Reiss, P. (2007), Empirical Models of Entry and Market Structure, Handbook of Industrial Organization, Vol.3, forthcoming

Bresnahan, T.F. and Reiss, P.C: (1991), Entry and Competition in Concentrated Markets, Journal of Political Economy 99, 977-1009. 
Bulow, J., Geanakoplos, J. and Klemperer, P. (1985), Holding Idle Capacity to Deter Entry, Economic Journal 95, 178-182.

Campbell, J.R. and Hopehayn, H.A. (2005), Market Size Matters, Journal of Industrial Economics 53, 1-25.

Collins, N. and L.E. Preston (1969), Price-Cost Margins and Industry Structure, Review of Economics and Statistics 51, 271-286.

Czarnitzki, D. and K. Kraft (2004a), Innovation indicators and corporate credit ratings: Evidence from German firms, Economics Letters 82, 377-384.

Czarnitzki, D. and K. Kraft (2004b), On the Profitability of Innovative Assets, ZEW Discussion Paper No. 04-38.

Dixit, A. (1979), A Model of Duopoly Suggesting a Theory of Entry Barriers, Bell Journal of Economics 10, 20-32.

Dixit, A. (1980), The Role of Investment in Entry Deterring, Economic Journal 90, 95-106.

Ellison, G. and Ellison S.F. (2000), Strategic Entry Deterrence and the Behavior of Pharmaceutical Incumbents Prior to Patent Expiration, Discussion Paper MIT.

Gaskins, D. W. (1971), Dynamic Limit Pricing: Optimal Pricing Under Threat of Entry, Journal of Economic Theory 3, 306-322.

Geroski, P.A. (1995), What Do We Know about Entry?, International Journal of Industrial Organization 13, 421-440.

Harrod, R.F. (1952), Economic Essays, New York: Macmillan.

Martin, S. (2002), Advanced Industrial Organization, second edition, Blackwell, Malden, MA.

McAfee, R.P., Mialon, H.M. and Williams, M.A. (2004), What is a Barrier to Entry?, American Economic Review Papers and Proceedings 94, 461-465.

Schmalensee, R. (1989), Inter-Industry Studies of Structure and Performance, in: R. Schmalensee and R.Willig (eds.) Handbook of Industrial Organization, volume 2, chapter 16, North-Holland, Amsterdam, 951-1009.

Shaanan, J. (1997), Idle Sunk Cost Capacity, Entry, and Profitability: An Empirical Study, Journal of Economics and Business 49, 267-283.

Shaked, A. and Sutton, J. (1982), Relaxing Price Competition through product Differentiation, Review of Economic Studies 49, 3-13.

Shaked, A. and Sutton, J. (1983), Natural Oligopolies, Econometrica 51, 1469-1483. 
Siegfried, J.J: and Evans, L.B. (1994), Empirical Studies of Entry and Exit: A Survey of the Evidence, Review of Industrial Organization 9, 121-155.

Spence, A.M. (1977), Entry, Capacity, Investment and Oligopolistic Pricing, Bell Journal of Economics 8, 534-544.

Sutton, J. (1991); Sunk Costs and Market Structure, MIT Press, Cambridge, MA.

Sutton, J. (1998), Technology and Market Structure, MIT Press, Cambridge, MA.

Sutton, J. (2007), Market Structure: Theory and Evidence, Handbook of Industrial Organization, Vol.3, forthcoming.

Stigler, G.J. (1968), The Organization of Industry, Chicago University Press, Chicago, IL.

Verbeek, M. (2000), A guide to modern econometrics, John Wiley \& Sons, West Sussex.

v. Weizsäcker, C.C. (1980), A Welfare Analysis of Barriers to Entry, Bell Journal of Economics 11, 399-420. 